International Journal of English Literature and Social Sciences
Vol-6, Issue-3; May-Jun, 2021

Peer-Reviewed Journal

\title{
Speaking Skill Problem Encountered by Vocational School Freshmen and Seniors Viewed from Their Own Perspectives
}

\author{
Afif Al Baironi Haka ${ }^{1}$, Abdul Asib ${ }^{2}$, Slamet Supriyadi ${ }^{3}$
}

\begin{abstract}
${ }^{1}$ Graduate School of English Education Department, Teacher Training and Education Faculty, Universitas Sebelas Maret, Indonesia Email: AfifhakaW@Gmail.com

${ }^{2}$ Graduate School of English Education Department, Teacher Training and Education Faculty, Universitas Sebelas Maret, Indonesia Email: abdulasib@yahoo.com

${ }^{3}$ Graduate School of English Education Department, Teacher Training and Education Faculty, Universitas Sebelas Maret, Indonesia Email: pripus.lppmuns@yahoo.co.id
\end{abstract}

Received: 16 May 2021; Received in revised form: 13 Jun 2021; Accepted: 20 Jun 2021; Available online: 27 Jun 2021 (C2021 The Author(s). Published by Infogain Publication. This is an open access article under the CC BY license (https://creativecommons.org/licenses/by/4.0/).

\begin{abstract}
The present study investigated the speaking skills problems encountered by Vocational School freshmen and seniors from their own perspectives. . The researcher used purposive sampling in selecting the participants of this research. To this end, 60 vocational school students (30 freshmen and 30 seniors) from SMK Negeri 2 Bandar Lampung participated in the study by completing a speaking skills problems questionnaire. To triangulate the data, the participants of the study also sat an in-depth interview. The results of the study revealed that some affective, cognitive, and behavioral aspects were among the major problem-creating factors for the freshmen's and seniors' speaking skills. Furthermore, freshmen's and seniors' results showed that overall there were no significant difference between the freshmen's and the seniors' perspective toward speaking skills problems. The results of both questionnaire and interview showed that the most speaking skill problem freshmen and seniors encountered is the affective aspect. They both are afraid to make pronunciation mistakes while speaking English. This problem inhibits students', speaking skill to develop.
\end{abstract}

Keywords-freshmen, perspective, senior, speaking skill problem.

\section{INTRODUCTION}

Speaking is building and sharing meaning in a variety context through the process of delivering message using verbal and non-verbal symbol (Chaney and Burk, 1998: 13). It forms a meaningful communication between two or more people for getting response and how to follow appropriately cultural rules in communication circumstances. Therefore, the speakers do not only produce word randomly but also they need to establish a meaningful communication.

Burkart (1998) stated that speaking involves three areas of knowledge. First area is mechanic (pronunciation, grammar, vocabulary). This means speakers are using the right words in the right order with the correct pronunciation. Next, function (transaction and interaction) comes as the second. It is when speakers know clarity of message is important (transaction) and exact understanding is not required (interaction). Third are social and cultural rules and norms (turn taking, rate of speech, length of pauses between speakers, relative roles of participant). As a result, speakers must have these knowledges in order to create a meaningful communication.

As important as speaking itself, teaching speaking seems important as well. Teaching speaking is considered needed for EFL students because speaking is being primary skill 
to human communication. Teaching speaking has goal that is communication efficiency (Kayi, 2006). It is about teaching student how to put their thought into words so that they are competent to communicate with native speakers naturally.

However, in daily teaching activities, the materials taught for speaking is not balance. Even though, we speak a lot in daily life, yet teacher still often to discuss writing and reading. Speaking is rarely taken as materials to be taught during English lesson. As we know the goal of learning English is to be able to communicate, the speaking skill should be given more time to be learned and practiced. If the students do not have many chances to speak in English class, they will lose their motivation and lost interest in learning English especially speaking.

A limited chance to speak in English class provided by the teacher may be one problem that students have in developing their speaking skill. Yet, a variety of speaking problem had by students. The factor why speaking skill has many problems is due to English is a foreign language in Indonesia. Learners consider speaking in English is difficult because it requires great courage as well as preparation to speak in new language. They must memorize new vocabularies and learn grammar and pronunciation at the same time.

The difficulties had by student in speaking skill are varied. In Indonesian education curriculum, Learners start learning English at junior high school. For the first year students in vocational school, they just know English for 3 years. The problem they have is probably different with the seniors which already learn English for six years. And the materials given are not the same as well. It causes a variety of problems for them. The problems may be recognized by teachers but the students may have better understanding about their own problems in speaking skill.

The reason why this research selects the freshmen and senior students is to find out the problems of learning speaking skill in each stage and to investigate what factors causing the problems. The research questions of this research are to find out the most often speaking skill problems faced by vocational school freshmen and seniors based on their own perspectives and to observe whether or not there is any difference between freshmen's and seniors' perspectives about speaking skill problems. It is expected that the results can give the teachers a solution of fixing the problem and make the speaking class more effective.

The definition of speaking by Nunan (2003, p. 48) defines "speaking is a productive aural/oral skill which consists of producing systematic verbal utterances to convey meaning". Burns and Joyce (1997) add that speaking is an interactive process which involves producing, receiving and processing information to construct meaning. From the definition mentioned, it can be said that Speaking is known as a productive skill which requires ability to construct meaning in order to get an understanding from the listeners.

The students have their own difficulties in learning the language. Particularly in improving speaking skill is not easy for the students. According to Ur (1991, p. 121), the problems of speaking skill are 1) inhibition in which students are often inhibited about trying to say things in a foreign language in the classroom, 2) nothing to say: they have no motive to express themselves beyond the guilty feeling that they should be speaking, 3) low or uneven motivation: This problem is compounded by the tendency of some students to dominate, while others speak very little or not at all, and 4) mother tongue use.

Perspective is known as the way of people thinking about something. This relates to the definition delivered by Murphy and Murphy (1931: 615) that perspective is primarily a way of being set towards or against certain things. Robbins (2005) adds that perspective is manner, disposition, feeling and position with regard to a person or thing, tendency or orientation especially in the mind.

According to Perloff (2016), perspective is a psychological construct, a mental and emotional entity that inheres in, or characterizes a person. They are complex and an acquired state through experiences. Allport (1935) described perspective as a mental and neural state of readiness, organized through experience, exerting a directive or dynamic influence upon the individual's response to all objects and situations with which it is related. Hence, each person tends to have various perspectives of one particular thing. Since their points of views are influenced by what they have experienced in their life.

In summary, perspective is manner, disposition, feeling, position, and a way of being set towards or against certain things which are complex and an acquired state through experiences. In this case students are expected to give their perspective of speaking skill problems fairly and accurately based on what they have experienced during English class especially speaking session.

\section{RESEARCH METHOD}

This study used qualitative research since it wanted to find out the students' English speaking problems based on their perspective and the researcher thought that this method was more acceptable to be applied. As stated by Fraenkel and Wallen (1996: 442), if the researchers want to investigate the quality of relationships, activities, 
situations, or materials, qualitative research is used. Here, the researcher obtained an in-depth look at a particular individual, situation or a set of materials.

The subject of this research was chosen based on purposive sampling. Therefore, the present research took one freshmen class that consisted of 30 students and one senior class that consisted of 30 students. This subject was chosen because this study wanted to find out students' perspectives regarding speaking skill problems.

This research was held in 2019-2020 academic year. . For the purpose of this study, the data were obtained directly from research participants and were in the form of interview transcripts, audio recordings, field notes and documents. Therefore, this study used questionnaires and interview to collect the data.

The questionnaire used for the data collection was a 20item speaking skill problems questionnaire adapted from a speaking skill problems questionnaire from Irismet (2006). Each questionnaire statement was oriented on a Likert scale ranging from 1 (strongly disagree) to 4 (strongly agree).

Next, In-depth interviewing was used in this study. The interviewer goes into the interview with the aim of discussing a limited number of topics, sometimes as few as one or two, and frames the questions on the basis of the interviewee's previous response. Mack et al (2005: 30) argue that in-depth interview is an effective qualitative method for getting people to talk about their personal feelings, opinions, and experiences.

In this present research, the data which were obtained through the questionnaire and interview were analyzed by using interactive model proposed by Miles \& Huberman (2014:10).. The result of the questionnaire was calculated by using the Microsoft Excel computer program in the form of percentages. The transcribed interview, field note and the students' score were analyzed to find out the information that could represent the research questions by giving a code. When the organized information was displayed in the form of words, the researcher then made conclusions.

\section{FINDINGS AND DISCUSSION}

The freshmen's perspectives were identified from the result of the questionnaire which was obtained from a freshmen class with 30 students. Then it had been calculated by using the Microsoft Excel computer program. The result of this calculation shows which of questionnaire item that the students agree the most.

Table 1: Freshmen's Most Frequently Reported Speaking Skills Problems

\begin{tabular}{|c|c|c|}
\hline RANK & NUMBER OF ITEM & SCORE \\
\hline 1 & Q1 & 118 \\
\hline 2 & Q10 & 115 \\
\hline 3 & Q3 & 114 \\
\hline 4 & Q4 & 114 \\
\hline 5 & Q5 & 112 \\
\hline
\end{tabular}

As indicated in table 1, freshmen mostly agreed that they experienced fear of making mistakes in their pronunciation while speaking English. They thought that speaking English with good pronunciation was not easy. They could enjoy the English class when there was no speaking activity. They just liked such of activity in which a teacher had a big role in the class. They said that they like English lesson and had no problem learning it but having fear of making pronunciation mistakes really hold them back from speaking English. This was also supported by the interview.

R: Do you like learning English?

S: I like to study English when there was no speaking activity.

I will be afraid if teacher asks me to speak.

$R$ : What makes you afraid of speaking English?

S: I am afraid to make pronunciation mistakes during speaking. I have bad pronunciation maybe due to lack of training. (Interview)

Next, not having enough vocabulary is the second most speaking problem freshmen faced. They do not speak English during the lesson due to lack of vocabulary. They cannot express their idea about the topic being discussed or even do not understand about it. Not having enough vocabulary also has an impact to their speaking performance. They become shy and not confident to speak English during class because they fear making mistakes. Here are some quotations of the interview.

$R$ : how about vocabularies? Have you mastered many of them?

S: I think my vocabulary is so few.

I can not express what I want to say. Sometimes, I can not understand the topic being discussed.

$R$ : does it affect your speaking performance in class?

S: of course, I lose my confidence and felt shy during my speaking. I am afraid to make a mistake moreover if my friends notice it.

Shyness is also a problem that is mostly faced by students while speaking English. It can be seen on the table 1 that 
shyness is on the third most speaking skill problem. Based on the results of the questionnaire, out of 30 students in freshmen class 24 students strongly agree and 6 students agree that shyness is a speaking skill problem. They cannot deliver their ideas well in English if teacher asked students to share theirs. It prevented them to speak English well even though they know what they want to say. The interview is below.

R: Shyness often makes students cannot deliver ideas in English. What about you? Has it happened on you too?

S: Yes, I think I was mostly shy when I was speaking English.

$R$ : did it affect the way you deliver your idea?

S: yes it did, I became so stiff and could not deliver my idea well even though I want to say something.

Similar to shyness, the fourth most speaking skill problem found in freshmen's perspective came from their feeling or emotion. They lost their confidence if they spoke English. This feeling emerged due to the lack of vocabulary mastery. Confidence is important in speaking performance. If the students' confidence is low, they will rarely want to speak English or even they will avoid speaking English in Class.

Similar to freshmen perspectives data, the results of seniors' perspectives were collected by using speaking skill problems questionnaire. Then, the researcher also did an interview in order to strengthen the data trustworthiness. The score of each questionnaire item is ranked in the table 2 below.

Table 2. Senior Students' Most Frequently Reported Speaking Skills Problems

\begin{tabular}{|c|c|c|}
\hline RANK & NUMBER OF ITEM & SCORE \\
\hline 1 & Q1 & 117 \\
\hline 2 & Q3 & 111 \\
\hline 3 & Q19 & 109 \\
\hline 4 & Q4 & 108 \\
\hline 5 & Q5 & 108 \\
\hline
\end{tabular}

The table 2 shows that the most speaking skill problem based on seniors' perspective was Q1. It referred to the item number 1 on the questionnaire that is afraid of making pronunciation mistake while speaking English. Students were afraid to speak English during class due to bad pronunciation. It made them lose the confidence to speak. One of quotations of the interview is below.
R: What makes you afraid to speak English?

$S:$ for me, it is pronunciation sir.

R: Why are you afraid?

S: Since I rarely speak English, my pronunciation is poor.

I am not confident to speak with teachers or my friends.

Next, Shyness is the second most speaking skill problem. Based on the questionnaire result, 24 students strongly agreed, 6 students agreed, and none of them disagreed. So this means that most of students are shy while speaking English. Shyness made them not able to deliver their ideas well in English. Here is one of the interviews with students.

R: Have you felt shy during speaking?

S: yes I have, I sometimes hold back from speaking due to shyness.

$R$ : Does it affect your speaking performance?

S: yeah it does, I cannot state my idea well. I know what I want to say however I cannot express it well.

Neglect is the third most speaking skill problems found by the researcher. Neglect belongs to behavioral aspect of speaking skill problem. So it is the attitude which students show to speaking English. In this case, neglect means students give not enough care to speaking English due to their poor pronunciation. Most students agreed that they tended to behave like this during speaking class. One of interview transcripts is below.

$R$ : what is the factor that makes you not to speak at all?

$S:$ for me, it's pronunciation.

$R:$ and why?

S: my pronunciation is bad. When I hear my friend speaking with good pronunciation, I just do not want to be compared, so I do not speak English.

The fourth most speaking skill problem came from affective aspect of students. Confidence is important in speaking English. If students' confidence is low, their performance will decrease. Many senior students in the class in which the research was held agreed that they lost their confidence while speaking English. According to them, not having enough vocabulary was the cause of their low confidence during speaking. One of the interview transcripts is below:

R: Confidence is important in Speaking English. Don't you think so?

S: yes sir, I agree with you.

$R$ : What made you lose your confidence while speaking English? 
S: I lose the confidence to speak when I cannot perform well.

R: Hmm, I mean what is the cause of your low confidence during speaking?

S: This was mostly caused by lack of vocabulary.

The results of the questionnaire, corroborated by the interview findings, indicated that freshmen and senior students basically shared the same speaking skill problems. This means that vocational school students' speaking skill problems probably continue to exist even after several years of studying at high school level.

The first speaking skill problem commonly shared by freshmen and seniors was afraid of making pronunciation errors while speaking English. Ramasari's (2017) study on STKIP PGRI students also indicated that one of their oral communication problems was afraid of making pronunciation error during speaking class. Vocational school students tended to be passive during speaking class. Students explained that their fear of making mistakes in front of their classmates was the reason for not speaking in the class. They were more relaxed to speak English just to their teacher rather than in front of their friends. They preferred to keep silent rather than they got negative evaluation from their friends. Thus, teacher should find a suitable teaching method which can boost students' confidence to speak in front of friends as well as improve their pronunciation.

The second speaking skill problem commonly shared by freshmen and seniors was shyness during speaking English. The participants in the interview stated they cannot deliver their ideas well in English if teacher asked students to share theirs. It inhibited them to speak English well even though they know what they want to say. Corroborating this, Ur (1996:78) believes that one of the factors which causes difficulty in speaking is inhibition in which it is created by simply shyness.

The third speaking problem commonly shared by the majority of vocational school freshmen and seniors was the lack of vocabulary mastery as a factor that decreased students' confidence. The students which are in low confidence cannot deliver their ideas or information well during speaking. It would be good if the English instructor often asks students to perform speaking English in many settings. This opportunity will improve the confidence and the variety of speaking themes or settings will enrich students' vocabulary mastery.

The fourth of most speaking skill problem commonly shared by freshmen and seniors was having high anxiety while speaking English. In the interview, the students mentioned that anxiety hindered them to deliver their ideas in English well. Therefore, speaking anxiety really affected students' speaking performance. This result was in line with the results of Wahyuni (2015). The result of her research showed that speaking anxiety has significant impact to students' speaking achievement. Furthermore, she suggested teachers to maintain close relationship with students and to use both Indonesian and English as the instruction in order to slowly erase the anxiety of students.

\section{CONCLUSION}

To Based on students' perspective, freshmen and senior students' most speaking skill problems are likely the same. In their 5 highest ranking items of speaking skill problems, they have 4 same problems. However, they have 1 problem exclusively for them. For the freshmen, they have problems in vocabulary. They do not posses enough vocabulary so that they often use words which are not suitable for the context. Next, the senior students' exclusive problem is bad pronunciation. It affected their behavior toward speaking. They do not want to speak English at all because of it.

The study revealed that both freshmen and senior students have the same most speaking skill problem they encountered. They felt afraid of making pronunciation mistakes while speaking English. The students tend to become passive in class. This is because they were too anxious to speak English with their peers and teachers. Therefore, the teacher role is very important to help students to cope with their fear toward pronunciation mistakes.

English teachers should try to design and organize various classroom activities to help students to get relieve and to decrease students' fear. English teachers need to teach and train students to be supportive of one another in class. Therefore, the teacher should give extra time for the students to make some preparation before they speak up. Teacher's understandings are very crucial since there was one important interaction occur in the class, teacher and students interaction

Moreover, Teachers may set goals for students in learning English, provide students knowledge concerning general English and English grammar, and inspire students to learn. The suitable techniques may help students to learn English and improve their speaking skill. By understanding students' speaking skill problem from their perspective, teachers are expected to design materials which are not only able to enrich knowledge but also relieve students' fear toward mistakes that hold them from speaking. 


\section{REFERENCES}

[1] Chaney, A. L., \& Burk, T. L. (1998). Teaching Oral Communication in Grades $K-8$. Boston: Allyn and Bacon.

[2] Burkart, Grace Stovall, (1998). Spoken Language: What It Is and How to Teach It. Washington DC: Center for Applied Linguistics

[3] Kayi, Hayriye. (2006). Teaching Speaking: Activities to Promote Speaking in a Fourth Language. USA: University of Nevada.

[4] Nunan, D. ( 2003). Practical English Language Teaching. New York : Mc Graw Hill.

[5] Burns, A. \& Joyce, H. (1997). Focus on Speaking. Sydney: National Center for English Language Teaching and Research.

[6] Ur, Penny. (1991). A Course in Language Teaching: Practice And Theory. Cambridge: Cambridge University Press

[7] Murphy, G., \& Murphy, L. B. (1931). Experimental Social Psychology. New York: Harper \& Brothers

[8] Robbins, S. P. (2005). Essentials of Organisational Behaviour. New Jersey: Pearson.

[9] Perloff, Richard M. (2016). The Dynamics of Persuasion: Communication and Attitudes in the Twenty-First Century. Oxon: Routledge

[10] Allport, Gordon. (1935). "Attitudes," in A Handbook of Social Psychology. Worchester: Clark University Press.

[11] Fraenkel, Jack. R., and Norman E. Wallen. (1996). How to Design and Evaluate Research in Education. Michigan University: McGraw-Hill Higher Education.

[12] Irismet, K. (2006). The Analysis Of The Speaking Problems In The English Language Teaching Department At Ahmed Yasawi International Kazakh Turkish University (Master's Thesis). Retrieved from http://www.belgeler.com

[13] Mack, N., Woodsong, C., McQueen, K. M. Guest, G. and Namey, E. (2005). Qualitative research methods: a data collector's field guide [Online]. Carolina: Family Health International. Available at: http://www.fhi.org [Accessed 12 December 2018]

[14] Miles, M. B., \& Huberman, A. M. (2014). Qualitative Data Analysis, A Methods Sourcebook, Edition 3. USA: Sage Publications.

[15] Ramasari, M. (2017). Students Pronounciation Error Made in Speaking for General Communication. Linguistic, English Education and Art (LEEA) Journal, 1(1), pp. 37-48.

[16] Ur, Penny. (1996). A Course in Language Teaching: Practice And Theory. Cambridge: Cambridge University Press

[17] Wahyuni, Satriawati E. (2015). Students' Anxiety in the Speaking Class and its Consequences toward their Speaking Achievement. Surakarta: UNS. 